\title{
The Impacts of Oil Price and Exchange Rate on Food Prices in Nigeria
}

\author{
Umar Bala* $\quad$ Muhammad Mustapha Abdullahi \\ Department of Economics, Faculty of Social and Management Sciences, Bauchi State University, Gadau, P.M.B \\ 065, Yuli Campus, Bauchi State, Nigeria
}

\begin{abstract}
No financial support has been received for the research
Abstract

This empirical research examined the interconnecting relationship between oil price, exchange rate and food prices in Nigeria. The study applied annual time series data from 1972 to 2016. Autoregressive Distributed Lag (ARDL) techniques were used in the process of estimating the model. The main results disclosed that there is a long run association among the considered variables. The error correction term indicates significant negative sign. Among the two independent variables in the model, exchange rate is affecting food price more than the oil price counterpart since some of the food items are imported. The result has robust implication on policy recommendations in Nigeria. Food production has a vital role in influencing food prices in Nigeria. The Central Bank of Nigeria must consider exchange rate as a factor influencing food price in its quest for achieving inflation target.
\end{abstract}

Keywords Oil price; exchange rate; food price; ARDL; Nigeria

DOI: $10.7176 / \mathrm{JESD} / 10-8-08$

Publication date: April $30^{\text {th }} 2019$

\section{Introduction}

The changes in commodity price in the energy market and the fluctuation of exchange rate has influenced both imported and domestically produced food prices. This assertion has become a serious issue of discussion particularly as its affects crude oil prices which is the highest contributor of revenue to Nigeria's revenue generation source. These changes have a great role in every economy depending on to the extent and how much the economy is relying on oil while it also has a significant impact on the global economy. Recently, oil price having reached a maximum threshold level has dropped to a so far lowest level, which significantly affects several oil exporting countries including Nigeria. It is on record that oil price performs a major role in determining the overall economic activities of oil producing nations, which create an external imbalance (Rebucci and Spatafora 2006). In oil-exporting countries, when oil price dropped, exchange rate depreciates and inflationary pressure emerged. Oil price changes create serious concern in a country's economy that heavily depends on exporting or importing oil products. Ordinarily, this happens due to lack of diversification in the general economic activities.

Oil price shock does not have effect only on energy products but significantly influence inflation rate in an economy (Gómez-loscos et al., 2012). The rise and decline in crude oil price in 1970 and 1980 instantly adjusted inflation. Increases in oil price were transferred into general price level in an economy, via producer price index and consumer price index leading to an increase in inflation (Basnet and Upadhyaya, 2015). High level of inflation would produce unfavorable economic outcomes such as increase in uncertainty levels associated with expected business profits (Kofi et al., 2015). In addition, relationship between petroleum prices and inflation is not static. It has been changing dramatically with time. In the 1970s their relationship was relatively strong and statistically robust. In the 1980s, however, there were little evidence that changes in crude oil price influence inflation. Despite the higher crude oil price in the $2000 \mathrm{~s}$, casual observation shows that inflation is lower in many countries compared with the rises in oil price and inflation in 1970s (Gregorio et al., 2007). Oil price changes trigger a balance of payments crisis and forcing exchange rate to depreciate (Sargent and Wallace, 1981). It is also important to note that movements in the prices of particularly goods such as oil lead to persistent changes in the aggregate price level (Ball and Mankiw, 1994). Inflation may have a substantial inertial component arising from the sluggish adjustment of inflationary expectations (Chopra, 1985).

In 2014, oil price dropped drastically in response to which most of the oil exporting countries including Nigeria were affected. The Central Bank of Nigeria adopted contractionary majors to resist the shock of falling oil revenue. These measures included increasing the monetary policy rate (MPR), restricting of some imported items from abroad to reduce the demand for foreign currency to further protect the domestic currency. In the same vain the Nigerian government also reviewed the 2015 budget, reduced the anticipated oil price benchmark, and significantly cut down on capital expenditure. While foreign reserves were falling, the exchange rate policy of devaluation and depreciation of the Nigerian currency were put in place. Earlier than 2014, the rate of inflation was relatively moderate of between 7 to 8 percent. When oil price dropped, the price of goods and services accelerated, in 2015; inflation hit double-digit, basically due to the lower oil price and the weakening of Nigerian currency (Chuhan-Pole et al., 2015).

Figure 1 displays the trends between food price index, oil price and exchange rate in Nigeria during the period 
of this study. Between 1970 and 1985, when oil price fluctuated, exchange rate remained reasonably stable, while the food price index shows little response. From 1986 to 1998 food price index shows little positive increment even though oil price remains averagely unstable and exchange rate showed some evidence of depreciation. From 1999 to 2014 new evidences emerged from the relationships whereby, from 2001 to 2008 oil price increase, exchange rate depreciated and the food price index still moved upward. While oil prices dropped in 2008 and 2009 , exchange rate showed stronger depreciation rate; s more than the proportional changes earlier noticed. There was also a noticeable increase in oil and food prices. When in 2009 , oil price increase, exchange rate still depreciated while food price shows more positive movement. It was easily noticeable that, since 2007 the food price was increasing faster than before. This trend tried to illuminate how the variables are responding and interconnected with each other.

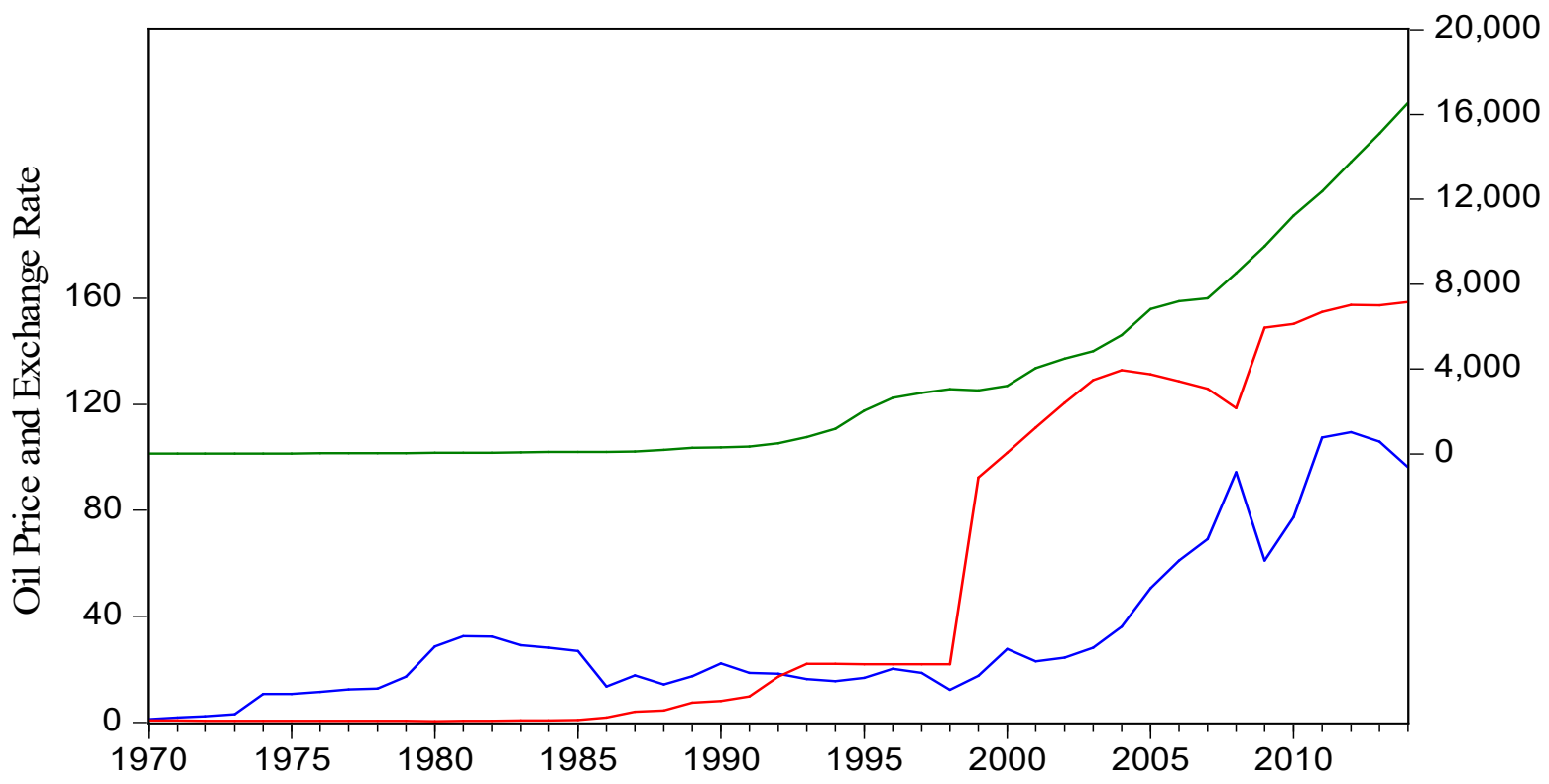

Figure 1:

Food CPI, Oil Price and Exchange Rate

Source: World Bank Online Database

There are a lot of empirical studies that attempted to investigate the factors influencing food prices and its relationship with other economic indicators. Pala (2013), applied Johansen cointegration test to establish the connection between oil price and food price. The outcomes revealed that their coefficient sign is not constant but varied based on structural changes. Reboredo (2012), applied weekly data from 1998:1 to 2011:4 to study the determinants of the relationship between oil prices and wheat price, soybean price and corn price. The study includes time differences. The results indicate that food price changes are not initiated by oil price increases. Gardebroek and Hernandez (2013) use multi-variant GARCH methods to investigate the effect of oil price, ethanol and corn price by analyzing annual data in the period of 1997 to 2011 . The study established that there was no sign or indication of energy prices influencing corn price in the United States.

Timilsina et al. (2011) on the other hand used a global computable general equilibrium (CGE) framework and focused on Oil price, biofuels and food supply in panel analysis. The results revealed that direct impacts of higher oil price reduce world food supply. Jongwanich and Park (2009), studied nine Asian countries and found that the degree of the pass-through between oil price and their domestic prices are limited. Hu et al. (2013) studied selected Asia and Pacific countries by applying structural vector auto-regression procedure. The study reveals different results based on the country depend on. Chen et al. (2010) found that oil price changes absolutely affect grain prices. Dillon and Barrett (2016) investigate east Africa countries with the results indicating that food price was affected indirectly via the cost of transportation when oil price increase and not directly via the oil price itself. The studies focus on oil price on macroeconomic (Kumar 2009; Rafiq et al. 2009; Iwayemi and Fowowe 2011; Ahmed and Wadud 2011; Razmi et al. 2015).

Some studies concentrated on the level of exchange pass-through; Correa and Minella, 2006; De-Gregorio et al. 2007; Kara and Öğünç, 2009; Jiang and Kim, 2013; Aron et al., 2014 have all confirmed sig a significant relationship between oil price and food prices. Mirdala (2014) studied how exchange rate changes are transmitted into the overall economic activities in Eurozone. The result was that it plays a dynamic role in influencing their foreign relation with trading partners. Ranadive (2015) applied Indian monthly data of 2009:4 to 2013:5 to investigate the level of exchange rate influence on domestic prices. The results revealed that there is partial pass- 
through from exchange rate to domestic and import prices. While Oriavwote and Oyovwi (2012) investigated the determinants of Nigerian exchange rate. Exchange rate shocks are transmitted into aggregate inflation at a much faster rate in emerging economies than in industrials economies. Choudhri, et al., (2005); Devereux and Yetman, (2002). Doğan, (2013) also found similar results in his study using Turkish time series data ranging from 2001:10 to 2011:3 of average nominal Turkish Lira (TL) against the U.S. dollar, and the manufacturing industry producer price index (MPI). The pass-through is affected positively by the aggregate demand conditions. In particular, when the economy is growing, exchange rate changes are transmitted to prices to a larger extent than otherwise. MaríaDolores, (2009) studies eleven NMSs of 12 countries (Bulgaria, Cyprus, the Czech Republic, Estonia, Hungary, Latvia, Lithuania, Poland, Romania, Slovakia, Slovenia and Turkey) from January 2000 to July 2007 using vector autoregressive (VAR) model and found that exchange rate pass-through is larger for these developing countries.

\section{Methodology}

The Autoregressive Distributed Lag (ARDL) procedure was used to estimate the cointegration model. The methods were selected based on its dynamic facility and capacity to detect the short and long run with the error correction term. The procedure has numerous advantages over other symmetric methodologies. It is suitable and applicable to estimating $\mathrm{I}(0)$ and $\mathrm{I}(1)$ variables or a combination of the two. ARDL is also useful for both small and large sample observations (Pesaran and Smith, 1995.)

\section{Model Specification}

The model is based on previous studies that defined food price as a function of oil price (Ibrahim, 2015), that studied oil and food prices while other studies have seen inflation rate as being influenced by exchange rate.

lf $p_{t}=\alpha_{0}+\beta_{1} \operatorname{lop}_{t}+\beta_{2}$ lex $+\varepsilon_{t}$

Where: lf $p$ is log of food price CPI, lop is log of oil price, lfp is the log of exchange rate and $\varepsilon$ is the error term respectively. Since the model consists the properties of econometric specification, the short-run and the long-run dynamics could be captured through the unrestricted error correction term as an ARDL equation as in Equation (2):

$$
\Delta l f p_{t}=\alpha_{0}+\sum_{i=1}^{p} b_{1} \Delta l f p_{t-1}+\sum_{i=1}^{p} c_{1} \Delta l o p_{t-1}+\sum_{i=1}^{p} d_{1} \Delta l e x_{t-1}+{ }_{1} \text { lf } p_{t-1}+\partial_{2} \operatorname{lop}_{t-1}+\partial_{3} \text { lex }_{t-1}+\mu_{t}
$$

From the above ARDL cointegration (Equation 2), the estimation of long-run and short-run parameters are treated separately after establishing cointegration.

Estimation of the long-run equation:

lf $p_{t}=\alpha_{0}+\sum_{i=1}^{p} b_{1}$ lf $p_{t-1}+\sum_{i=1}^{p} c_{1} l o p_{t-1}+$

$\sum_{i=1}^{p} d_{1} l e x_{t-1}+\mu_{t}$

Estimation of the short-run equation:

$\Delta l f p_{t}=\alpha_{0}+\sum_{i=1}^{p} b_{1} \Delta l f p_{t-1}+\sum_{i=1}^{p} c_{1} \Delta l o p_{t-1}+\sum_{i=1}^{p} d_{1} \Delta l e x_{t-1}$

Estimation of the error correction term:

$E C T_{t}=l f p_{t}-\alpha_{0}-\sum_{i=1}^{p} b_{1} l f p_{t-1}-\sum_{i=1}^{p} c_{1} l o p_{t-1}-\sum_{i=1}^{p} d_{1} l e x_{t-1}$

The model in equation (5) measures the error correction term sign that is adjustment speed toward long-run equilibrium. However, the negative sign of ECT confirms the existence of cointegration among the variables in the model. To avoid spurious results, several diagnostic checks are conducted.

The research applied Nigerian time series observation on annual basis ranging from 1970 to 2016 . Food price represents a proxy of food price index $(100=1985)$, the oil price was a proxy of the spot price of Nigerian crude (Bonny light) and an official exchange rate of the Nigerian currency relative to US dollar was used. The data are extracted from the Central Bank of Nigeria and World Bank online databases and were converted into natural log foams.

\section{Findings}

To examine the property of the data before conducting the estimation of the dynamic models, the following tests are required. In the first step, we examine the non-stationary or integration properties of the time series, using the widely used augmented Dickey-Fuller (ADF) and Phillips-Perron (PP) unit root tests, in the second step, given that the variables are non-stationary. Table 1 presents the testing of the unit root results; food price, oil price and exchange rate were stationary at 1 percent significance level after first differencing. Food price in PP test is 
stationary at level, but if considered as 10 percent, even though the ADF test was not detected. Table 1 Stationarity Test

\begin{tabular}{ccllll}
\hline & & \multicolumn{2}{c}{ Augmented Dickey-Fuller (ADF) } & \multicolumn{2}{c}{ Philip Perron (PP) } \\
& Variable & Constant without Trenc & Constant with Trend & Constant Without Tren & Constant with Tren \\
\hline$f p$ & $I(0)$ & 1.0903 & -2.4023 & 0.9214 & $-3.4015^{*}$ \\
& $I(1)$ & $-4.2057 * * *$ & $-4.5458^{* * *}$ & $-9.9082^{* * *}$ & $-10.1780^{* * *}$ \\
op & $I(0)$ & -1.875783 & -2.478198 & -1.992397 & -1.922460 \\
& $I(1)$ & $-4.938890^{* * *}$ & $-5.007194 * * *$ & $-5.332596 * * *$ & $-5.244315^{* * *}$ \\
ex & $I(0)$ & -1.698046 & -2.066588 & -1.703800 & -2.145764 \\
& $I(1)$ & $-5.800340^{* * *}$ & $-5.697899^{* * *}$ & $-5.747757 * * *$ & $-5.630553^{* * *}$ \\
\hline
\end{tabular}

Note: $\&$ trend is constant with trend SIC is used to select the optimum lag order in ADF and PP test and $\mathbf{a}$ and $\mathbf{b}$ denote significance level at 1 percent and 5 percent.

Figure 2 presents the selection of optimal lags in ARDL cointegration equation, based on the assumption that residuals are serially uncorrelated. The research used most recent ARDL procedure to determine the best model. Akaike Information Criterion (AIC) was used to detect the number of lags required in the model that is free from autocorrelation problem (Al-jammal, 2010). The estimation found that ARDL 443 is the optimal number of lags required in our model that is a more reliable model. Akaike Information Criteria (top 20 models)

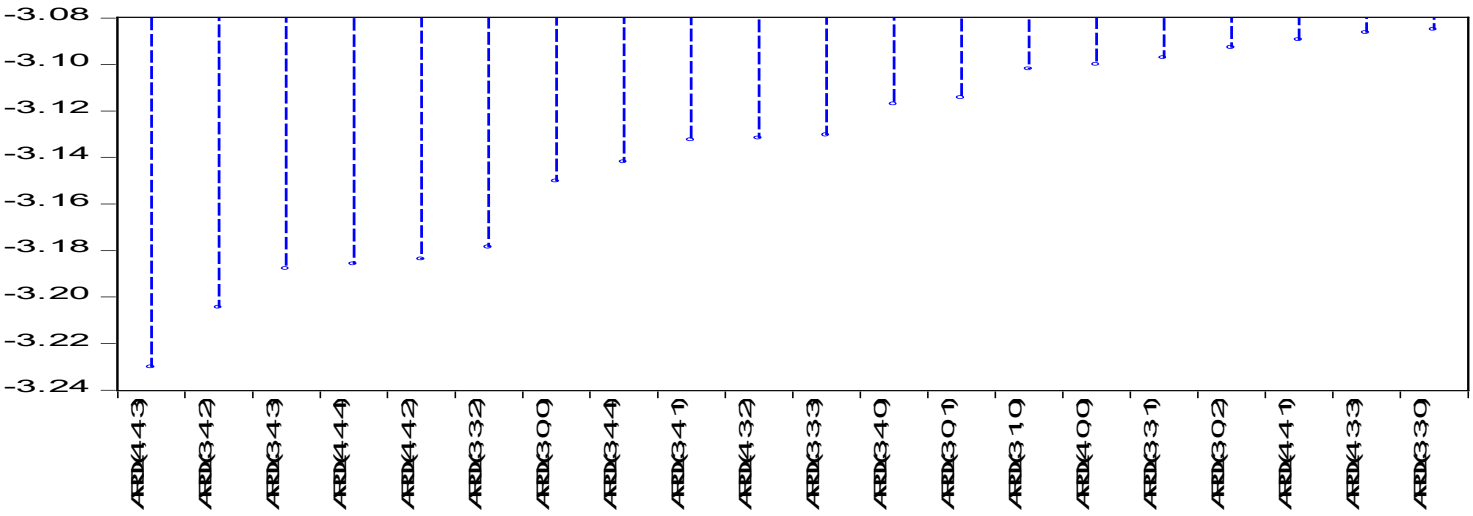

Figure 2: Optimal Lag Selection Criteria

\section{Cointegration Test}

Table 2 presents the ARDL estimated results of cointegration between food price, oil price and exchange rate, whereby equation (2) was used in establishing the relationship. We followed the ARDL procedure by calculating the F-statistic and compared with the F-statistic provided by (Narayan and Smyth, 2005). In condition, cointegration can only be found, when the calculated F-statistics is greater than the Narayan tabulated upper bounds F-statistic. The calculated F-statistic of 5.2405 and the upper bounds at 5 percent level of significance is 4.088 . The conclusion therefore is that the variables are cointegrated. They are moving in the same direction or that they share a common relationship in the long run.

Table 2: ARDL Bound Test Results

\begin{tabular}{|c|c|c|c|c|c|}
\hline Bounds test result & F-statistics & Lag & Level of & Unrestricted & intercept \\
\hline & & & significance & and no trend & \\
\hline & & & $1 \%$ & 4.310 & 5.544 \\
\hline lf $p_{t}=f\left(\operatorname{lop}_{\mathrm{t}}\right.$, lex $\left._{\mathrm{t}}\right)$ & 5.2405 & 3 & $5 \%$ & 3.100 & 4.088 \\
\hline & & & $10 \%$ & 2.592 & 3.454 \\
\hline
\end{tabular}

Note: F-statistics is greater than the upper bound at $5 \%$ level, which indicates the existence of long-run relationship. Also, lag 2 was selected as the optimal lag length after testing different lags length suggested by Akaike information criterion (AIC).

The study further investigated the model by estimating the short and the long run coefficients having established the presence of cointegration amongst the variables. Table 3 presents the ARDL 443 short and the long run coefficients and the level of significance. The long-run estimated results reveal that the food price is positively affected by oil price and exchange rate. Oil price increase by 1 percent, causes food price to increase by 0.0632 at 10 percent significant level, while a change in exchange rate by 1 percent, causes food price to increase by 0.2134 at 1 percent significance level. The results are not much surprising considering Nigeria as an oil producing country, an increase in oil price will produce more income and increase the amount of money in circulation. The positive exchange rate means depreciation in exchange rate thus showing that the results are in line with the theoretical basis that depreciation of the currency will produce inflation since the purchasing power of domestic currency 
becomes weaker.

Table 3 ARDL Estimated Short and the Long Run Coefficients

\begin{tabular}{cllccc}
\hline $\begin{array}{l}\text { Independent } \\
\text { variables }\end{array}$ & \multicolumn{1}{c}{$\begin{array}{c}\text { Short-run } \\
\text { Coefficient }\end{array}$} & T ratio & $\begin{array}{c}\text { Independent } \\
\text { Variables }\end{array}$ & $\begin{array}{c}\text { Long-run } \\
\text { Coefficient }\end{array}$ & T ratio \\
\hline$D(L F P(-1))$ & -0.1201 & $(-0.7780)$ & $L O P$ & $0.0632^{*}$ & $(1.8632)$ \\
$D(L F P(-2))$ & $0.5411^{* * *}$ & $(4.0935)$ & $L E X$ & $0.2134^{* * *}$ & $(21.9992)$ \\
$D(L F P(-3))$ & $0.3094^{*}$ & $(1.7401)$ & $C$ & $3.3915^{* * *}$ & $(31.7204)$ \\
$D(L O P)$ & -0.0035 & $(-0.1276)$ & - & - & - \\
$D(L O P(-1))$ & $-0.0668^{*}$ & $(-2.0532)$ & - & - & - \\
$D(L O P(-2))$ & $-0.0826^{* * *}$ & $(-3.0238)$ & - & - & - \\
$D(L O P(-3))$ & $-0.0718^{* *}$ & $(-2.5179)$ & - & - & - \\
$D(L E X)$ & 0.0203 & $(0.7162)$ & - & - & - \\
$D(L E X(-1))$ & $-0.0916^{* *}$ & $(-2.7726)$ & - & - & - \\
$D(L E X(-2))$ & $-0.0635^{*}$ & $(-1.7940)$ & - & - & - \\
$C o i n t E q(-1)$ & $-0.4725^{* * *}$ & $(-4.8453)$ & - & - & - \\
$R^{2}$ & 0.9894 & - & - & - & - \\
$B P G$ & $1.4685(0.7482)$ & - & - & - & - \\
$L M$ & $1.0535(0.1636)$ & - & - & - & - \\
\hline
\end{tabular}

CointEq(-1) is the error correction term, $B P G$ and are $L M$ Breusch-Pagan-Godfrey Heteroskedasticity test and Breusch-Godfrey Serial Correlation LM test up to the lag order given in the parenthesis respectively

\section{Conclusion}

This empirical research tried to examine the interconnecting relationship between oil price, exchange rate and food price in Nigeria, with annual data from 1972 to 2016. Autoregressive Distributed Lag (ARDL) bounds testing techniques were used in the process of estimating the model. The main results disclosed that there is a long run association among the considered variables. The long-run estimated results revealed that food price is positively affected by oil price and exchange rate. Oil price increase by 1 percent, causes food price to increase by 0.0632 at 10 percent significant level, while the exchange rate increase by 1 percent, causes food price to increase by 0.2134 at 1 percent significance level. The error correction term confirms the results by a negative sign and statistically significant. Between the two main indicators in the model, food price was less affected by the oil price when compared with the exchange rate in the long run.

The results were anticipated, considering that Nigeria is an oil producing country, an increase in oil price will produce more income and increase the amount of money in circulation. The positive exchange rate which also depicts depreciation of the local currency is also in line with the theoretical basis that depreciation of the currency will produce inflation since the purchasing power of domestic currency becomes less. The result has robust implication in policy and recommendation in Nigeria. Central Bank of Nigeria must consider exchange rate more as a factor influencing food price in Nigeria to achieve the desired inflation target. The results led to the conclusion that direct implication oil price on food price is less, when compared with the implication through exchange rate.

\section{References}

Ahmed, A. H. J., \& Wadud, I. K. M. M. (2011). Role of oil price shocks on macroeconomic activities: An SVAR approach to the Malaysian economy and monetary responses. Energy Policy, 39(12), 8062-8069. http://doi.org/10.1016/j.enpol.2011.09.067

Aron, J., Creamer, K., Muellbauer, J., \& Rankin, N. (2014). Exchange rate pass-through to consumer prices in South Africa: Evidence from micro-Data. Journal of Development Studies, 50(1), 165-185. http://doi.org/10.1080/00220388.2013.847178

Ball, L., \& Mankiw, N. G. (1994). Asymmetric price adjustment and economic fluctuations. The Economic Journal, 104(423), 247-261. http://doi.org/10.2307/2234746

Basnet, H. C., \& Upadhyaya, K. P. (2015). Impact of oil price shocks on output, inflation and the real exchange rate: evidence from selected ASEAN countries. Applied Economics, 47(29), 3078-3091. http://doi.org/10.1080/00036846.2015.1011322

Chen, S.-T., Kuo, H.-I., \& Chen, C.-C. (2010). Modeling the relationship between the oil price and global food prices. Applied Energy, 87(8), 2517-2525. http://doi.org/10.1016/j.apenergy.2010.02.020

Chopra, A. (1985). The speed of adjustment of the inflation rate in developing countries: A study of inertia. $I M F$ Staff Papers, 32(4), 693-733.

Choudhri, E. U., Faruqee, H., \& Hakura, D. S. (2005). Explaining the exchange rate pass-through in different prices. Journal of International Economics, 65, 349-374. http://doi.org/10.1016/j.jinteco.2004.02.004

Chuhan-Pole, P., Calderon, C., Kambou, G., Boreux, S., Buitano, M. M., Korman, V., \& Kubota, M. (2015). Africa's Pulse, October 2015, (No. 22722), The World Bank. 
Correa, A. da S., \& Minella, A. (2006). Nonlinear mechanisms of the exchange rate pass-through - A Phillips curve model with threshold for Brasil. Working Paper Series Do Banco Central, (122), 1-31. http://doi.org/10.1590/S0034-71402010000300001

De-Gregorio, J., Landerretche, O., \& Neilson, C. (2007). Another pass-through bites the dust? Oil prices and inflation. Economía, 7(2), 155-196. http://doi.org/10.1353/eco.2007.0014

Devereux, M. B., \& Yetman, J. (2002). Menu costs and the long-rub output-inflation trade-off. Economics Letters, 76(1), 95-100. http://doi.org/10.1016/S0165-1765(02)00022-8

Dillon, Br. M., \& Barrett, C. B. (2016). Global oil prices and local food prices: evidence from East Africa. American Journal of Agricultural Economics, 98(1), 154-171. http://doi.org/10.1093/ajae/aav040

Doğan, B. Ş. (2013). Asymmetric behavior of the exchange rate pass-through to manufacturing prices in Turkey. Emerging Markets Finance and Trade, 49(3), 35-47. http://doi.org/10.2753/REE1540-496X490303

Gardebroek, C., \& Hernandez, M. A. (2013). Do energy prices stimulate food price volatility? Examining volatility transmission between US oil, ethanol and corn markets. Energy Economics, 40, 119-129. http://doi.org/10.1016/j.eneco.2013.06.013

Gómez-loscos, A., Gadea, M. D., \& Montañés, A. (2012). Economic growth, inflation and oil shocks: are the 1970s coming back? Applied Economics, 44(35), 4575-4589. http://doi.org/10.1080/00036846.2011.591741

Hu, B., Alom, F., \& Ward, B. D. (2013). Macroeconomic effects of world oil and food price shocks in Asia and Pacific economies: application of SVAR models. OPEC Energy Review, 37(3), 327-372. http://doi.org/http://dx.doi.org/10.1111/opec.12015

Ibrahim, M. H. (2015). Oil and food prices in Malaysia: A nonlinear ARDL analysis. Springer Open Journal, 3(2), 1-14. http://doi.org/10.1186/s40100-014-0020-3

Iwayemi, A., \& Fowowe, B. (2011). Impact of oil price shocks on selected macroeconomic variables in Nigeria. Energy Policy, 39(2), 603-612. http://doi.org/10.1016/j.enpol.2010.10.033

Jiang, J., \& Kim, D. (2013). Exchange rate pass-through to inflation in China. Economic Modelling, 33, $900-912$. http://doi.org/10.1016/j.econmod.2013.05.021

Jongwanich, J., \& Park, D. (2009). Inflation in developing Asia. Journal of Asian Economics, 20(5), $507-518$. http://doi.org/10.1016/j.asieco.2009.07.004

Kara, H., \& Öğünç, F. (2009). Inflation targeting and exchange rate pass-through: The Turkish experience. Emerging Markets Finance and Trade, 44(6), 52-66. http://doi.org/10.2753/REE1540-496X440604

Kofi, P. A., Zumah, F., Mubarik, A. W., Ntodi, B. N., \& Darko, C. N. (2015). Analysing inflation dynamics in Ghana. African Development Review, 27(1), 1-13.

Kumar, S. (2009). The macroeconomic effects of oil price shocks: empirical evidence for India. Economic Bulletin, 29(1), 15-37.

María-Dolores, R. (2009). Exchange rate pass-through in Central and East European countries. Eastern European Economics, 47(4), 42-61. http://doi.org/10.2753/EEE0012-8775470403

Mirdala, R. (2014). Exchange rate pass-through to consumer prices in the European transition economies. Procedia Economics and Finance, 12(March), 428-436. http://doi.org/10.1016/S2212-5671(14)00364-5

Oriavwote, V. E., \& Oyovwi, D. O. (2012). The determinants of real exchange rate in Nigeria. International Journal of Economics \& Finance, 4(8), 150-160. http://doi.org/10.5539/ijef.v4n8p150

Pala, A. (2013). Structural Breaks, Cointegration, and Causality by VECM Analysis of Crude Oil and Food Price. International Journal of Energy Economics and Policy, 3(3).

Rafiq, S., Salim, R., \& Bloch, H. (2009). Impact of crude oil price volatility on economic activities: An empirical investigation in the Thai economy. Resources Policy, 34(3), 121-132. http://doi.org/10.1016/j.resourpol.2008.09.001

Ranadive, R. R. (2015). Transmission mechanism of exchange rate pass-through in India. Foreign Trade Review, 50(4), 263-283. http://doi.org/10.1177/0015732515598589

Razmi, F., Mohamed, A., Chin, L., \& Habibullah, S. M. (2015). The effects of oil price and US economy on Thailand's macroeconomy: The role of monetary transmission mechanism. International Journal of Economics and Management, 9, 121-141.

Reboredo, J. C. (2012). Do food and oil prices co-move? Energy Policy, 49, $456-467$. http://doi.org/10.1016/j.enpol.2012.06.035

Rebucci, A., \& Spatafora, N. (2006). Oil Prices and Global Imbalances. IMF World Economic Outlook: Washington, DC.

Sargent, T. J., \& Wallace, N. (1981). Some unpleasant monetarist arithmetic. Federal Reserve Bank of Minneapolis Quarterly Review, 5(3), 1-17. http://doi.org/10.3386/w0867

Timilsina, G. R., Mevel, S., \& Shrestha, A. (2011). Oil price, biofuels and food supply. Energy Policy, 39(12), 8098-8105. http://doi.org/10.1016/j.enpol.2011.10.004 